\title{
A Study on Clinical Assessment of Antibiotic Used in Chronic Kidney Disease Patients
}

\author{
(Studi Penilaian Klinis Penggunaan Antibiotik pada Pasien \\ Penyakit Ginjal Kronis)
}

\author{
MITA RESTINIA ${ }^{1 *}$, HENNY LUCIDA², WASIF GILLANI S ${ }^{3}$ \\ 'Department of Community and Clinical Pharmacy, Faculty of Pharmacy Universitas Pancasila, \\ Jakarta, Indonesia \\ ${ }^{2}$ Faculty of Pharmacy, Andalas University, Padang, Indonesia \\ ${ }^{3}$ Discipline of Clinical Pharmacy, School of Pharmaceutical Sciences, USM, Malaysia
}

Diterima 13 Maret 2017, Disetujui 5 Juli 2017

\begin{abstract}
A 6-week longitudinal prospective study was conducted to assess the effectiveness and the safety antibiotic used in chronic kidney disease (CKD) patients in internal medicine ward. We compared white blood count and glomerular filtration rate before and after antibiotic used. The CKD patients who admitted in the internal medicine ward and age $\geq 18$ years old were included this study. Patients with incomplete laboratory data and renal replacement therapy were excluded in this study. The 25 patients who enrolled in this study were recruited. The majority gender of CKD was male $(64 \%)$, the mean of age was $61.52 \pm 14.17$ years old with length of stay (LOS) was $6.92 \pm 4.05$ days. The highest number of patients was in CKD stage $3(n=10,40 \%)$ and was followed by CKD stage $2(n=6,24 \%)$. Most of them were diagnosed community acquired pneumonia. Tablet azithromycin $(n=16,64 \%)$ then Cefotaxime intra venous injection (IV) $(\mathrm{n}=6,24 \%)$, and Ceftazidime IV $(\mathrm{n}=5,20 \%)$, Cloxacillin IV $(n=4,16 \%)$ were the most antibiotics prescribed. Generally patients had been prescribed appropriate dose of antibiotic and $88 \%$ of them showed improved white blood count. In contrast, the glomerular filtration rate of $44 \%$ CKD patients was getting worse. In conclusion, this study clearly indicate the CKD patients require close monitoring to maintenance of renal function even the antibiotic had been prescribed appropriately.
\end{abstract}

Keywords: chronic kidney disease, antibiotic, clinical assessment.

\begin{abstract}
Abstrak: Sebuah studi prospektif longitudinal 6 minggu dilakukan untuk menilai efektivitas dan antibiotik keamanan yang digunakan pada pasien penyakit ginjal kronis (CKD) di bangsal pengobatan internal. Kami membandingkan jumlah darah putih dan tingkat filtrasi glomerulus sebelum dan sesudah antibiotik digunakan. Pasien CKD yang dirawat di bangsal penyakit dalam dan usia $\geq 18$ tahun dimasukkan dalam penelitian ini. Pasien dengan data laboratorium yang tidak lengkap dan terapi penggantian ginjal dikeluarkan dalam penelitian ini. 25 pasien yang terdaftar dalam penelitian ini direkrut. Jenis kelamin mayoritas CKD adalah laki-laki (64\%), rata-rata usia adalah 61,52 $\pm 14,17$ tahun dengan lamanya tinggal (LOS) adalah 6,92 $\pm 4,05$ hari. Jumlah pasien terbanyak adalah pada CKD stadium $3(\mathrm{n}=10$, $40 \%)$ dan diikuti oleh CKD tahap $2(n=6,24 \%)$. Sebagian besar dari mereka didiagnosis menderita radang paru-paru. Tablet azitromisin $(n=16,64 \%)$ kemudian Cefotaxime injeksi intra vena (IV) $(n=$ 6, 24\%), dan Ceftazidime IV ( $\mathrm{n}=5,20 \%)$, Cloxacillin IV $(\mathrm{n}=4,16 \%)$ adalah antibiotik yang paling diresepkan. Umumnya pasien telah diberi dosis antibiotik yang tepat dan $88 \%$ dari mereka menunjukkan peningkatan jumlah darah putih. Sebaliknya, tingkat filtrasi glomerulus dari $44 \%$ pasien CKD semakin buruk. Kesimpulannya, penelitian ini jelas menunjukkan pasien CKD memerlukan pemantauan ketat terhadap pemeliharaan fungsi ginjal bahkan antibiotik telah diresepkan dengan tepat.
\end{abstract}

Kata kunci: penyakit ginjal kronis, antibiotik, penilaian klinis.

\footnotetext{
* Correspondence Author, Hp: 085263693378

e-mail: mita_restinia09@ymail.com
} 


\section{INTRODUCTION}

CHRONIC kidney disease (CKD) is defined as the presence of abnormalities of kidney structure or function or a reduction in glomerular filtration rate (GFR) for period of three months or longer ${ }^{(1)}$. Hwang et.al reported that the prevalence of CKD has increased in many countries, mainly in the US (13.1\%), Japan (12.9-15.1\%), Australia (11.2\%), Norway (10\%), Taiwan (9.8-11.9\%), China 3.2-11.3\%), Korea (7.2$13.7 \%)$, Thailand $(8.45-16.3 \%)^{(2)}$. In West Malaysia, the prevalence of CKD was $9.07 \%{ }^{(3)}$.

The presence of CKD and its complication during therapy remain as unresolved problem. The CKD patients generally have co-morbidity that contributed to a decline in the renal function, such as infectious disease. Pneumonia and sepsis were found in higher rate in hospitalized CKD patients compared with non CKD patients ${ }^{(4)}$. CKD patients have major infectious complication 3 to 4 times the general population ${ }^{(5)}$. McDonald et.al (2014) had reviewed the various references and they found pre-dialysis kidney patients have more risk to get infection ${ }^{(6)}$.

Antibiotic is one of medicine associate with infection. The majority of antibiotics are eliminated by kidney. Some of them are contraindicated with CKD's patients and need dose adjustment. Alahdal \& Elberry (2011) reported that most of drug need dose adjustment was antibiotic and rarely adjust by physician ${ }^{(7)}$. Inappropriate dose are common in patients with renal problem which can cause adverse drug reaction and poor clinical improvement ${ }^{(8,9)}$. About $20.91 \%$ in CKD patients had been prescribed inappropriate dose in a Chinese tertiary teaching hospital $^{(10)}$. Farag et.al (2014) reported that dossing error in prescribed antibiotic was found in CKD patients $^{(11)}$. As reported in China, dosage errors for antibiotics prescribed for CKD patients were in the range of $38.85 \%-60.3 \%{ }^{(12)}$.

The dose adjustment in CKD patients is done based on patient's creatinine clearance and $\mathrm{GFR}^{(1)}$. The GFR also have correlation with renal function and able to determine the safety of drug utilization. There are many kinds of equation to calculate the GFR, such as CKD-EPI equation. The WBC of patients is an essential parameter in order to optimize the effectiveness of antibiotic used in CKD patients. Nowadays, there were many publications associated with drug prescribed in CKD patients. However, the research related to assess antibiotic used clinically and correlation with renal function is still limited. Therefore, the current study was carried out to clinical assessment the effectiveness and the safety the drug utilization of antibiotic according to laboratory data
GFR and WBC before and after using antibiotic in CKD patients.

\section{MATERIALS AND METHODS}

MATERIALS. Subject in this study was patients with CKD who hospitalized in internal medicine ward at teaching hospital in Kelantan-Malaysia. The data was recorded by patient's medical record and nurse record. We used Pharmacist Workup of drug therapy pharmacy clinical clerkship to daily follow up the patients daily.

MethodS. Study Design and Patient Selection. A 6-week longitudinal prospective study was conducted to assess clinically drug utilization of antibiotic in CKD patients at teaching hospital. The evaluation was carried out by comparing GFR before and after using antibiotic to assess the safety of antibiotic used to renal function. Comparing WBC before and after using antibiotic to determine the correct treatment associate with infection also performed.

During the period of study, CKD patients who admitted in internal medicine ward and age $\geq 18$ y.o were included this study. The incomplete laboratory data (GFR, WBC) before and after using antibiotic, renal replacement therapy were excluded in this study. The data collection and comparing GFR, WBC between before and after antibiotic used.

The demographic data of patients (gender, age, and length of stay), antibiotic utilization and laboratory data (serum creatinine, WBC before and after antibiotic used) were extracted from patient's medical record, nurse record, and interview directly patients. GFR was calculated by using CKD-EPI equation (2002) by National Kidney Foundation method according to Kidney Disease Outcomes Quality Initiative Guideline:

eGFR $=141 * \min ($ standardized Scr/k,1) $\alpha$ * $\max ($ standardized Scr/k,1)-1.209*0.993Age * 1.018 [if female] * 1.159 [if black]

Abbreviation and Units

eGFR = estimated glomerular filtration rate $\left(\mathrm{mL} / \mathrm{min} / 1.73 \mathrm{~m}^{2}\right)$

Scr : serum creatinine $(\mathrm{mg} / \mathrm{dL})$

$\mathrm{K} \quad: 0.7$ (females) or 0.9 (males)

$\alpha \quad:-0.329$ (females) or -0.411 (males)

$\min \quad:$ indicates the minimum of $\mathrm{Scr} / \mathrm{k}$ or 1

$\max \quad$ : indicates the minimum of Scr/k or 1

Age in years

The stage of CKD were classified by GFR that refer to the National Kidney Foundation Kidney Disease Outcome Quality Initiative (K/DOQI) $\left(2002^{(1)}\right.$ as presented in Table 1.

Clinical Assessment. Clinical assessment was conducted by GFR and WBC. These parameters 
Table 1. The Stage of CKD according to K/DOQI ${ }^{(1)}$

\begin{tabular}{lll}
\hline Stage & \multicolumn{1}{c}{ Description } & GFR (mL/min $\left./ .73 \mathrm{~m}^{2}\right)$ \\
\hline 1 & Kidney damage with normal or increased GFR & $\geq 90$ \\
2 & Kidney damage with a mild decrease in GFR & 60 to 89 \\
3 & Moderate decrease GFR & 30 to 59 \\
4 & Severe decrease in GFR & 15 to 29 \\
5 & Kidney failure & $<15$ (or dialysis) \\
\hline
\end{tabular}

was divided into three categories improved, worse, and similar. The term of improved defined as GFR increased after using antibiotic and WBC in normal value and or decreased. The term of worsen means GFR decreased after using antibiotic and WBC became higher than before using antibiotic. Similar means GFR value similar between before and after using antibiotic.

Analysis of Data. The descriptive analysis was conducted to analyze characteristic patients associate with CKD and correlate the laboratory data (GFR and WBC) to assess the effectiveness and the safety of clinically the antibiotics used in CKD patients.

\section{RESULTS AND DISCUSSION}

Patient Characteristic. In all, during the study period, the $30 \mathrm{CKD}$ patients were enrolled in this study by primary screening. Then, only 25 patients were fulfilled the inclusion and exclusion criteria. Patients were coded from P1 to P25. The majority gender of hospitalized CKD patients in internal medicine was male $(64 \%)$, the mean of age was $61.52 \pm 14.17$ y.o, with rank 38-85 y.o. The mean of length of stay (LOS) was 6.92 \pm 4.05 days with range (3-22 days). The highest number of patients was in CKD stage $3(\mathrm{n}=10,40 \%)$ and was followed by CKD stage 2 $(n=6,24 \%)$. Patient characteristic in this study was presented in Table 2.

According to Table 2, CKD patients who get infection hospitalized 6 to 7 days generally. Patients with CKD stage 5 or end stage renal failure showed higher LOS in internal medicine ward. A possible explanation for this could be patients with the worsened renal function required more treatment and these patients were geriatric who had age more than 60 y.o. Therapy of geriatric patients was more complicated than adults due to comorbidities which need longer LOS. The incidences CKD was increased dramatically with age and linear with the stage

Table 2: Characteristics of enrolled CKD patients in internal medicine ward.

\begin{tabular}{|c|c|c|c|c|c|}
\hline \multicolumn{2}{|c|}{ Stage of $\mathrm{CKD}(\mathrm{n}, \%)$} & \multicolumn{2}{|c|}{ Gender, $\mathrm{n}(\%)$} & \multirow{2}{*}{$\begin{array}{c}\text { Age, Mean } \\
(y .0)\end{array}$} & \multirow{2}{*}{$\begin{array}{l}\text { LOS, Mean } \\
\text { (day) }\end{array}$} \\
\hline & & Male & Female & & \\
\hline CKD stage 1 & $(4,16 \%)$ & $4(16 \%)$ & & $55.25 \pm 13.89$ & $6.50 \pm 2.52$ \\
\hline CKD stage 2 & $(6,24 \%)$ & $5(20 \%)$ & $1(4 \%)$ & $51.17 \pm 12.47$ & $\begin{array}{l}0.30 \pm 2.32 \\
7.33 \pm 2.25\end{array}$ \\
\hline CKD stage 3 & $(10,40 \%)$ & $6(24 \%)$ & $4(16 \%)$ & $65.90 \pm 1439$ & $6.00 \pm 3.30$ \\
\hline CKD stage 4 & $(1.4 \%)$ & & $1(4 \%)$ & 740000.00 & $600 \pm 0.00$ \\
\hline CKD stage 5 & $(4,16 \%)$ & $1(4 \%)$ & $3(12)-12$ & $69.25 \pm 8.38$ & $9.25 \pm 8.54$ \\
\hline Total & $(25.100 \%)$ & $16(64 \%)$ & $9(36 \%)$ & $61.52 \pm 14.17$ & $6.92 \pm 4.05$ \\
\hline
\end{tabular}

of CKD. In the US, NHANES also reported that individual aged 60 and older was more prevalent to get $\mathrm{CKD}^{(13)}$. The increasing age is contributed to risk of progress $\mathrm{CKD}^{(14)}$.

The Distribution of Chief Diagnose. In this study, we found eight kinds of the chief diagnose in CKD patient who admitted to hospital. The most of diagnose patients among CKD patients associated with infection was $\operatorname{CAP}(n=16,64 \%)$ then was followed by urosepsis $(n=2,8 \%)$ and $\mathrm{CCF}(\mathrm{n}=2,8 \%)$ as well as, presented in Figure 1.

The CAP is one of common infectious disease that infected lower respiratory tract by Streptococcus pneumonia, Haemophilus influenza, Moraxella catarrhalis. CAP is pneumonia not acquired in hospital or a long-term care facility ${ }^{(15)}$. Other study that linier with this research was Santra et.al (2015) who found that respiratory tract infection was the most infection in CKD patients ${ }^{(16)}$. The incidence density rate of pneumonia was 65.6 per 1000 person per year in CKD patients and 28.4 per 1000 person per year in person without $\mathrm{CKD}^{(17)}$. The serious complication in CKD patients was pneumonia also was reported by Viasus et.al (2011) $)^{(18)}$.

The Distribution of Co-Morbidity of Enrolled CKD Patients. Co-morbidity is the presence of one or more additional diseases co-occurring with a primary disease. Majority CKD patients had comorbidity. 10 co-morbidities were recorded in this study. The most co-morbidity among CKD patients in was diabetes mellitus $(n=10,35 \%)$ and then followed by hypertension $(n=8,28 \%)$ and anemia ( $n-$ 5, 20\%). Santra et.al also found the similar result ${ }^{(16)}$. In addition, $68 \%$ CKD patients had one co-morbidity and $20 \%$ patients were with 2 co-morbidities, $4 \%$

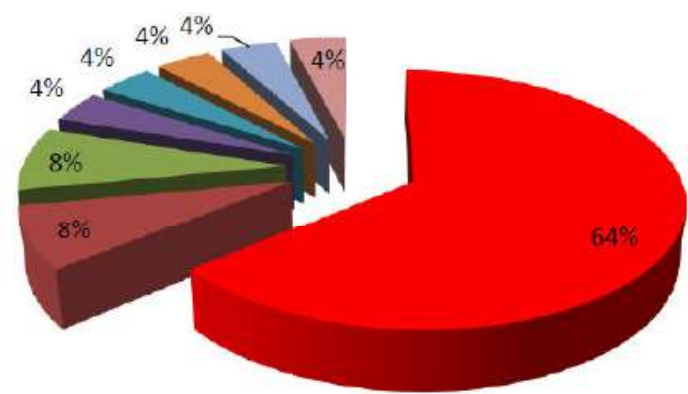

Figure 1.The distribution of Chief Diagnose in CKD patients. Abbreviation: CAP, community acquired pneumonia; $\mathrm{CCF}$, congestive cardiac failure

$$
\begin{aligned}
\text { Note: } & =\text { CAP } \\
& =\text { Urosepsis } \\
& =\text { CCF } \\
& =\text { Tuberculosis } \\
& =\text { Liver Abses } \\
& =\text { Trombofeblitis } \\
& =\text { Cellulitis }
\end{aligned}
$$$$
\text { nepsis }
$$ 
had 3 co-morbidities and $8 \%$ of them had none comorbidity (Figure 2). The presences of co-morbidity influenced the clinical outcome patients. Patients with the more co-morbidity had longer LOS. Other study was recorded that $23 \%$ of CKD patients suffered from diabetes ${ }^{(19)}$. More than 805 of CKD patients and diabetes have hypertension ${ }^{(20)}$.

Furthermore, The $20 \%$ of CKD patients showed anemia. Most of them were patients with CKD stage 5. It was related with a decrease in renal function to product erythropoietin. Anemia in CKD reduce the quality of life, increase the risk of cardiovascular disease, hospitalization, cognitive impairment, and mortality ${ }^{(21,22)}$.

The Pattern of Antibiotic Used. The prevalence infection in CKD patients is very common. Therefore most antibiotic have been prescribed among CKD patients. Figure 3 presented the utilization pattern of antimicrobials of enrolled patients with CKD. Fifteen kinds of antibiotics were recorded. The most antibiotic prescribed of enrolled CKD patients was Tab. Azithromycin $(n=16,64 \%)$ then IV. Cefotaxime $(n=6$, $24 \%$ ), and IV. Ceftazidime ( $\mathrm{n}=5,20 \%)$, IV. Cloxacillin $(\mathrm{n}=4,16 \%)$, and Tablet Amoxicillin+clavulanic acid $(n=3,12 \%) .53 .3 \%$ antibiotic was administered by intravenous and other antibiotics were administered by orally in tablet dosage form. The use of combination of azithromycin and $3^{\text {rd }}$ generation cephalosporin was predominant which comply with the National

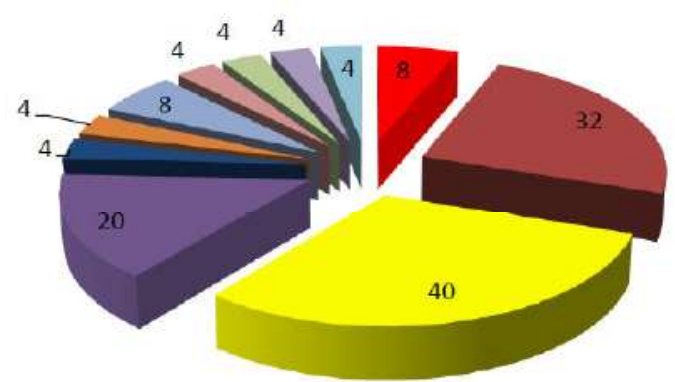

Figure 2 The Co-morbidity of Included CKD patients. Abbreviation: DM, diabetes mellitus; $\mathrm{CCF}$, congestive cardiac failure; HAP, hospital-acquired pneumonia.

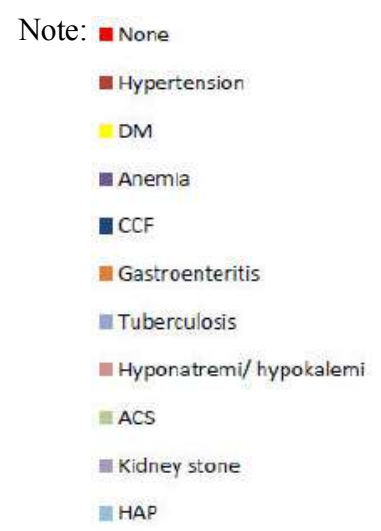

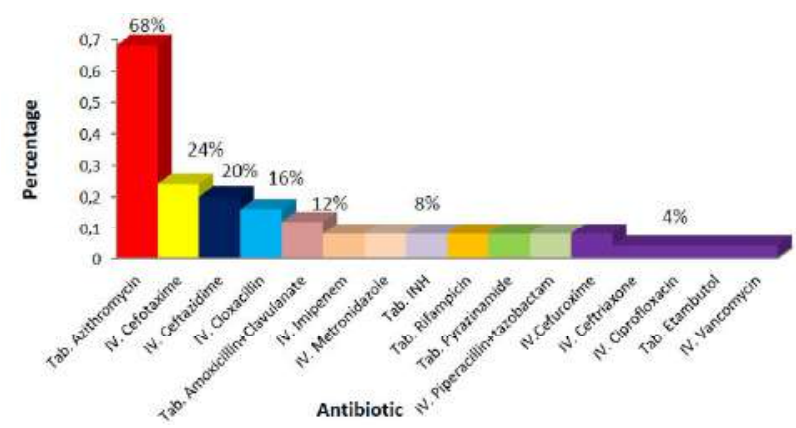

Figure 3: The utilization pattern of antimicrobials in CKD patients.

antibiotic guideline in Malaysia (2008) as the first line therapy for $\mathrm{CAP}^{(23)}$.

There were two approaches in prescribing antibiotic. The first approach is an empirical antibiotic and then definitive antibiotic. An antibiotic is selected without confirmed the culture and sensitivity test of microbial in the approach of empirical therapy. On the other hand, antibiotic was selected by confirmed culture and sensitivity test of microbial in definitive therapy. In this study, $84 \%$ enrolled CKD patients prescribed antibiotic by empirical and $18 \%$ of patients prescribed with definitive therapy. Bacteria Gram (+) cocci dan Gram (-) bacil, and Methicillin-resistant Staphylococcus aureus (MRSA) were recorded in culture and sensitivity test. The prescription antibiotic with definitive therapy is rare and limited. Thawani et.al (2006) reported the selection of antibiotics in the United States based on culture and sensitivity test results, only ranges between $20-25 \%$ while in Italy about $2 \%$ and in India only $1 \%$.

Patients who were MRSA infected in this study were hospitalized in the specific area in order to prevent nosocomial infection. Patient was given mark

Table 3: The adjusted doses utilization of antimicrobial in CKD patients.

\begin{tabular}{|c|c|c|c|c|c|c|}
\hline \multirow{2}{*}{$\begin{array}{l}\text { Antmicroblal } \\
\text { prescrited }\end{array}$} & \multirow{2}{*}{$\begin{array}{l}\text { Ronte of } \\
\text { athinstiation }\end{array}$} & \multirow[t]{2}{*}{ Usald dosape } & \multirow{2}{*}{\multicolumn{3}{|c|}{ 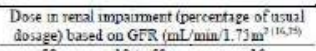 }} & \multirow[t]{2}{*}{ Note } \\
\hline & & & & & & \\
\hline Astithrouycin & Oxal & $500 \mathrm{mg}$ & - & - & - & $\begin{array}{l}\text { No adjustment } \\
\text { reeded }\end{array}$ \\
\hline Ceforaxime & N & $1102 g$ & $96 \mathrm{~b}$ & $960012 \mathrm{E}$ & $q 24 \mathrm{~h}(50 \%)$ & Adjustment \\
\hline Ceffaridime & w & 1 to 28 & $\mathrm{q}^{8}$ to $12 \mathrm{~h}$ & $\mathrm{q} 12+\mathrm{to} 24 \mathrm{~b}$ & $\mathrm{q}_{24}^{24 \text { to } 48 \mathrm{~h}}$ & Adjuxtmast \\
\hline Closacillin & Jv & $\begin{array}{l}25 \mathrm{~s} \\
25000 \mathrm{mg}\end{array}$ & & & & $\begin{array}{l}\text { reeeded } \\
\text { 2To adjuturent } \\
\text { roodad }\end{array}$ \\
\hline $\begin{array}{l}\text { Amosicillin+C] } \\
\text { avilanic acid }\end{array}$ & Oral & $\begin{array}{l}250 \text { to } 500 \mathrm{mz} \\
\text { eq } 81\end{array}$ & Q \$ b & $Q 8$ to $12 \mathrm{~b}$ & Q24h & $\begin{array}{l}\text { Adjustment } \\
\text { Deeded }\end{array}$ \\
\hline Inipereen & Iv & $\begin{array}{l}0.25 \text { to } 1 \mathrm{~g} \\
\mathrm{c} 5 \mathrm{t}\end{array}$ & $96 \mathrm{~b}$ & $912 \mathrm{~h}$ & $924 \mathrm{~b}$ & $\begin{array}{l}\text { Adjuttment } \\
\text { needed }\end{array}$ \\
\hline Metrondidazole & Nv & $400 \mathrm{mg} q-8 \mathrm{~b}$ & $q^{6-81}$ & $q^{6-81}$ & $\mathrm{q} 12 \mathrm{~b}$ & $\begin{array}{l}\text { Adjustuent } \\
\text { nooddd }\end{array}$ \\
\hline INH & Oral & $300 \mathrm{me} \mathrm{a} 24 \mathrm{~h}$ & - & - & - & No advustment \\
\hline Rifampicin & Oral & $600 \mathrm{mg} \mathrm{q} 24 \mathrm{~h}$ & & & & No adivetmont \\
\hline Fyrazinamide & Onal & 750 mz q $24 \mathrm{~L}$ & - & - & - & No adjustment \\
\hline Cefuroxime & IV & 0.75 to $1.5 \mathrm{z}$ & $88 \mathrm{~b}$ & 98 to $12 \mathrm{~b}$ & $812 \mathrm{~h}$ & Adustment \\
\hline Ceffinaxcre & Iv & $1.2 \mathrm{z}_{2}^{24 \mathrm{k}}$ & - & - & - & No adjuctment \\
\hline Ciprefloxacin & IV & 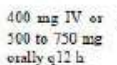 & $\mathrm{q} \cdot 12 \mathrm{~h}$ & $50.75 \%$ & $50 \%$ & $\begin{array}{l}\text { Adjuthont } \\
\text { Deeded }\end{array}$ \\
\hline Ethambarol & Oral & $800 \mathrm{mg} 024 \mathrm{~b}$ & & & & No \\
\hline $\begin{array}{l}\text { Piporzallint } \\
\text { Tazobactans }\end{array}$ & Iv & $\begin{array}{l}3.37510 .458 \\
96108 \mathrm{~L}\end{array}$ & $100 \%$ & 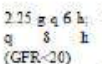 & $225 \mathrm{~g}$ ereay $8 \mathrm{~h}$ & $\begin{array}{l}\text { Adjustrmast } \\
\text { Deeded }\end{array}$ \\
\hline Vancomycin & IN & $\lg \in 12 \mathrm{~h}$ & & & $1 \mathrm{~g}$ exery $12 \mathrm{~h}$ & $\begin{array}{l}\text { Adjustment } \\
\text { sceded }\end{array}$ \\
\hline
\end{tabular}


Table 4: Clinical assessment of antibiotic used among stage of CKD.

\begin{tabular}{|c|c|c|c|c|c|c|c|c|c|c|c|c|c|}
\hline \multirow[t]{2}{*}{$\begin{array}{l}\text { Stage of } \\
\text { CKD }\end{array}$} & \multicolumn{2}{|c|}{$\begin{array}{l}\text { Antibiotic used } \\
N(\%)\end{array}$} & \multicolumn{2}{|c|}{$\begin{array}{c}\text { Appropriate dose } \\
N(\%)\end{array}$} & \multirow[t]{2}{*}{$\begin{array}{c}\text { GFRpre } \\
\left(\mathrm{mL} / \mathrm{min} / 1.73 \mathrm{~m}^{2}\right)\end{array}$} & \multirow[t]{2}{*}{$\begin{array}{c}\text { GFRPost } \\
\left(\mathrm{mL} / \mathrm{min} / 1.73 \mathrm{~m}^{2}\right)\end{array}$} & \multirow[t]{2}{*}{$\begin{array}{l}\text { WBCpre } \\
10^{3 / \mu I}\end{array}$} & \multirow[t]{2}{*}{$\begin{array}{c}\text { WBC post } \\
10^{3} / \mu \mathrm{L}\end{array}$} & \multicolumn{2}{|c|}{$\begin{array}{l}\text { Outcome } \\
\text { (WBC) }\end{array}$} & \multicolumn{3}{|c|}{$\begin{array}{l}\text { Outcome } \\
\text { (GFR) }\end{array}$} \\
\hline & Empinc & Definitive & yes & no & & & & & I & $\mathrm{W}$ & I & $\mathrm{W}$ & $\mathrm{s}$ \\
\hline CKD stage 1 & $4(16 \%)$ & - & $4(16 \%)$ & - & $103.00 \pm 8.98$ & $95 \pm 7.57$ & $8.60=1.63$ & $7.26 \pm 2.01$ & 4 & - & 1 & 3 & - \\
\hline CKD stage 2 & $5(20 \%)$ & $1(4 \%)$ & $6(24 \%)$ & - & $70.50=14.48$ & $76.67 \pm 14.51$ & $9.67 \pm 4.81$ & $12.15 \pm 358$ & 3 & 3 & 5 & 1 & - \\
\hline CKD stage 3 & $8(32 \%)$ & $2(8 \%)$ & $9(36 \%)$ & $1(4 \%)$ & $44.20=8.60$ & $48.50 \pm 11.81$ & $9.90 \pm 3.66$ & $8.05=1.90$ & 10 & - & 5 & 4 & 1 \\
\hline CKD stage 4 & $1(4 \%)$ & $-x^{-}$ & $1(4 \%)$ & - & $24.00=0.00$ & $23 \pm 0.00$ & $8.40=0.00$ & $6.70=0.00$ & 1 & - & - & 1 & - \\
\hline$C K D$ stage 5 & $3(12 \%)$ & $1(4 \%)$ & $3(12 \%)$ & $1(4 \%)$ & $11.50=2.89$ & $11.50=1.29$ & $14.67 \pm 5.85$ & $10.60 \pm 2.53$ & 4 & - & 1 & 2 & 1 \\
\hline Total & $21(84 \%)$ & $4(16 \% 0$ & $23(92 \%)$ & $2(8 \%)$ & $53.88 \pm 30.48$ & $55.76 \pm 29.37$ & $10.3416 \pm 4.29$ & $9.2584 \pm 3.04$ & 22 & 3 & 12 & 11 & 2 \\
\hline
\end{tabular}

MRSA isolated. For this patient, medical and feeding equipment were separated with other patients in the ward.

The Renal Adjusted Doses of Antimicrobial. In this study, an Antibiotic Guideline Malaysia was used to assess the appropriate antibiotic associate with diagnose. The dose in renal impairment was refer to "Use of antibacterial agents in renal failure" Livornes et.al (2004) and Santra et.al (2015) $)^{(16,25)}$. The dose adjustment was calculated by GFR using CKD-EPI equation. It was divided into three categories of GFR, such as, GFR $>50 \mathrm{~mL} / \mathrm{min} / 1.73 \mathrm{~m}^{2}$; GFR $=10-50 \mathrm{~mL} /$ $\mathrm{min} / 1.73 \mathrm{~m}^{2} ; \mathrm{GFR}<10 \mathrm{~mL} / \mathrm{min} / 1.73 \mathrm{~m}^{2}$.

There are antibiotic that do not need adjustment dose in CKD patients, for example, ceftriaxone, azithromycin, INH, rifampicin, Pyrazinamide and Cloxacillin. In addition, there were antibiotic that no adjustment needed in case GFR more than 50 $\mathrm{mL} / \mathrm{min} / 1.73 \mathrm{~m}^{2}$, such as Amoxicillin, imipenem, cefuroxime, Ciprofloxacin, piperacillin as presented in Table 3.

In this study, $17.68 \%$ of CKD patients need adjustment dose of antibiotics and remain did not adjusted $(\mathrm{n}=8.32 \%)$. Patients with GFR more than $50 \mathrm{~mL} / \mathrm{min} / 1.73 \mathrm{~m}^{2}$ did not need dose. Antibiotic was used in usual doses generally in patients who had GFR more than $50 \mathrm{~mL} / \mathrm{min} / 1.73 \mathrm{~m}^{2}$. Based on dose, the $92 \%$ CKD patients were given the appropriate dose based on their renal function. However $8 \%$ patients were prescribed inappropriate dose of antibiotic.

Tablet Azithromycin did not require dose adjustment in CKD patients because this drug is eliminated generally non renal and only $6 \%$ is excreted by renal ${ }^{(26)}$. Furthermore cefotaxime is $46 \%$ renal excreted. Hence, the prescription of this drug does not require dose adjustment in patients with mild and moderate renal impairment. In severe renal disease the doses need to decrease $50 \%$ from usual dose ${ }^{(25)}$.

Clinical Assessment Antibiotic Used in CKD Patients. Clinical assessment antibiotic used was performed by analysis of GFR and WBC before and after using antibiotic. It was conducted to find out the effectiveness of antibiotic used in infection treatment and the safety of these antibiotic associate with renal function. The result of clinical assessment antibiotic used was presented in Table 4.

Serum creatinine has good correlation with renal function. An increase in serum creatinine correlate with a decrease in renal function. In this study, $\mathrm{n}=12.48 \%$ patients performed improved GFR after using antibiotic. However $n=11.44 \%$ CKD patients demonstrated worse renal function after using antibiotic and $n=1.4 \%$ patients had similar GFR. The $81.82 \%$ patients who had worse renal function were prescribed an appropriate dose of antibiotic used. So, even antibiotic was prescribed correctly, CKD patients require close monitoring to maintenance of renal function.

A decrease in GFR presented in patients with CKD stage 1 and stage 4 . Most of them had co-morbidity more than one. An increase number of co-morbidity correlate with an increase number of drug prescribed to achieve the goal of treatment. Furthermore, an increase number of drug prescribed contributed to decline renal function.

Based on WBC, there were $(n=22.88 \%)$ patients showed improvement. It defined as the antibiotic was effective to treat the infection. However as $(n=3.12 \%)$ CKD patients who was found in CKD stage 2 performed increased $\mathrm{WBC}$ and the improvement of patient's condition did not appear. In this group, patient did not showed the decline of renal function generally.

\section{CONCLUSION}

The current study showed that predominantly CKD patients was prescribed an appropriate antibiotic used and effective to decrease WBC. Some of them showed the decline renal function. In conclusion, this study clearly indicate the CKD patients require close monitoring to maintenance of renal function even the antibiotic was prescribed appropriately.

\section{ACKNOWLEDGEMENT}

The author thank to all participants in the study, mainly for Mrs. Yelly Oktavia Sari who 
contributed and supported in data collection.

\section{REFERENCES}

1. National Kidney Foundation.Clinical practice guideline for chronic kidney disease: evaluation, classification and stratification. Am J Kidney Dis 2002.39:S1-266.

2. Hwang SJ, Tsai JC, Chen HC. Epidemiology, impact and preventive care of chronic kidney disease in Taiwan. Nephrology. 2010.15(2):3-9.

3. Hooi LS, Ong LM, Ahmad G, Bavanandan S, Ahmad NA, Naidu BM, Mohamud WN, Yusoff MF. A population-based study measuring the prevalence of chronic kidney disease among adult in West Malaysia. Kidney Int. 2013.84(5):103440. Doi:10.1038/ki.2013.220.Epub 2013 Jun 12.

4. United States Renal Data System. USRDS 2007. Annual data report.

5. Naqvi SB, Collins AJ. Infectious complication in chronic kidney disease. Adv Chronic Kidney Dis. 2006.13:199-204.

6. McDonald HI, Thomas SL, Nitsch D. Chronic kidney disease as a risk factor for acute communityacquired infection in high-income countries: a systematic review. BMJ Open. 2014.4:1-12. doi:10.1136/bmjopen-2013-004100.

7. Al-Loul M, Miller H,Alapati S, Stockton PA, Ledson MJ, Walshaw MJ. Renal impairment in cystic fibrosis patients due to repeated intravenous aminoglycoside use. Wiley online library. 2005.39(1):217-20.

8. Munar MY, Singh H. Drug dosing adjustments in patients with chronic kidney disease. American Family Physician. 2007.75(10):1487-96.

9. Dalrymple LS, Go AS. Epidemiology of acute infections among patients with chronic kidney disease. CJASN. 2008.3(5):1487-93. Doi:10.2215/ CJN.01290308.

10. Yang P, Chen N, Wang RR, Li L, Jiang SP. Inappropriateness of medication prescriptions about chronic kidney disease patients without dialysis therapy in a Chinese tertiary teaching hospital. Therapeutic and Clinical Risk Management. 2016.12:1517-24.

11. Farag A, Garg AX, Li L, Jain AK. Dosing errors in prescribed antibiotics for older persons with CKD: a retrospective time series analysis. Am J Kidney Dis. 2014.63(3):422-8.

12. Li P, Li F-j, Liu Y-g. Rationality antibiotic use in patients with chronic renal insufficiency. Eval Anal Drug-Use Hosp China. 2012.12(5):425-7.

13. United States Renal Data System. USRDS 2015. Annual data report: CKD in the United State volume 1. 2015.

14. Aronow WS, Fleg JL, Pepine JC, Artinian NT, Bakris G, Brown AS, et.al. ACCF/AHA 2011 expert consensus document o hypertension in the elderly: A report of the American College of Cardiology Foundation Task Force on Clinical Expert Consensus Document developed in collaboration with the American Academy of Neurology, American Geriatric society, American society for preventive cardiology, American Society of Hypertention, American Society of Nephrology, Association of Black Cardiologist, and European Society of Hypertention. J am Coll Cardiol. 2011.57:2037-114.

15. Lutfiyya N, Henley E, Chang LF, Reyburn SW. Diagnosis and treatment of communityacquired pneumonia. American Family Physician. 2006.73(3):442-50.

16. Santra S, Agrawal D, Kumar S, Mishra SS. A study on the drug utilization pattern in patients with chronic kidney disease with emphasis on antibiotics. Journal of integrative nephrology and andrology. 2015. 2(3): 85-9.

17. WenyuChou L, Che-Yi MD, Shu-Ming W MD, Chih-Chia MD, Ching Tzung MD, Jiung-Hsiun MD, et.al. Risk of pneumonia among patients with chronic kidney disease in outpatients and inpatient setting: A nationwide population-based study. Medicine. 2014.93(27):p e 174. Doi.10.1097/ MD.0000000000000174.

18. Viasus D, Garcia-Vidal C, Cruzado JM, Adamuz J, Adamuz J, Verdagur, Manresa F, Dorca J, Gudiol F, Carratal J. Epidemiology, clinical, features and outcome of pneumonia in patients with chronic kidney disease. Nephrol Dial Transplant. 2011.26:2899-906. doi.10.1093/ndt/gfq798.

19. Cavanaugh KL. Diabetes management issues for patients with chronic kidney disease. Clinical Diabetes. 2007.25(3):90-7.

20. Steigerwalt S. Management of hypertension in diabetic patients with chronic kidney diasease. Diabetes Spectrum. 2008. 21(1):30-6.

21. KDOQINational Kidney Foundation: KDOQI clinical practice guideline recommendation for anemia in chronic kidney disease. Am J Kidneys. 2006.47(3):11-145.

22. Baitt JL, Lin HY. Mechanism of anemia in CKD. JASN. 2012.23(10):1631-4. Doi.10.1681/ ASN.2011111078.

23. National Antibiotic Guideline. National Antibiotic Guideline. Malaysia: Ministry of Health Malaysia; 2008.

24. Thawani V, Kunda G, \& Paranjpe BF. Antibiotics: pharmacoepidemiology of antibiotics, our 
experience. Regional Health Forum WHO South East Asia Region. 2006. 2(2): 1343.

25. Livornese LL Jr, Gilbert B, Robbins P, Santoro J.Use of antimibacterial agents in renal failure. Infect Dis Clin North Am. 2004.18:556-67. 